\title{
Factors Affecting Organizational Commitment Among Bank Officers In Pakistan
}

\author{
Muhammad Anwar ul Haq*, Yan Jindong, Nazar Hussain, and \\ Zafar-uz-Zaman Anjum \\ (School of Management Wuhan University of Technology, Wuhan, P.R. China)
}

\begin{abstract}
In this study, we investigate the factors which are likely to affect the organizational commitment among bank officers in Pakistan, since the banking industry has been facing higher employee turnover. The theoretical framework of our study builds upon the theory of Social Exchange [1], the norm of reciprocity [2], and the theory of Perceived organizational Support [3, 4]. Data was collected by personally administered questionnaires. 147 officers working in different bank branches in Lahore participated in the study. Only those respondents were included in the study who had passed their probationary period. SPSS version 20 was used to analyze the data. The results reveal that there is a higher correlation between different supporting factors and organizational commitment of bank officers. Regression results show that all factors significantly predict organizational commitment. Factors affecting the organizational commitment of bank officers include rewards, support from supervisor, promotion opportunities, work-family support, and favorable conditions of the job. This study has implications for HR Policies to be devised in such a way as to focus on turnover intentions among the experienced employees. By employing such efforts the companies can easily retain their experienced human capital.
\end{abstract}

Key Words: bank officer, commitment, factors organization, Pakistan

\section{Introduction}

Organizational commitment as a construct has been wieldy discussed among in the organizational psychology literature. Organizational commitment is the willingness to continue employment with an organization, to be loyal to the employing organization, to put exert extra effort for the achievement of organizational goals, and the level of identification of employee's and his employing organization's goals [5]. However, Meyer and Herscovitch [6] disagree on the definition and the way we measure organizational commitment. The disagreement arises from the reason that organizational commitment may or may not be regarded as a psychological state. Moreover, the source of disagreement is also the behaviors depicting the commitment and the antecedent factors of commitment [7]. Given these differences on the differences on how to define the organizational commitment, the definition given by Mowday [8] more precisely defines organizational commitment. Organizational commitment is an individual's strength of identification with, and involvement in an organization [8].

There are three basic components of organizational commitment: (a) identification; a faith in the goals of an organization and reception of the same as well as the values of the organization: (b) effort; a strong willingness to exert efforts in order to achieve organizational goals (c) loyalty; a desire and continue as a part of the organization [9].

The literature suggests the factors which are supposed the effect the commitment of employees with their organization. According to Guzzo, Noonan [10] financial inducements are among the many factors which affect the commitment of employees. Other factors which have been outlined in the literature are supportive supervisors and employees, career advancement opportunities, [11], clarity of responsibilities, a say in setting the goals of the organization [12], and a fairness of dealings [13].

In this study we include five factors, namely; organizational rewards, supervisor support, favorable job conditions, family support, and career development opportunities. The objective of this study to find out the degree to which these factors predict the commitment of managerial level to their organization. This study has been conduct on the bank officers in the City of Lahore, Pakistan. In the next section we discuss the relevant literature, methodology, and the results respectively.

\section{Literature Review And Hypothesis Development}

All the financial and non-financial benefits which an employee gains by being an employee of an organization may be referred to as organizational rewards [14]. There are two kinds of rewards which are in practice to be provided to the employees. These intrinsic, and extrinsic rewards. Intrinsic rewards come in 
intangible form. These may include recognition, autonomy, and role in decision process. Extrinsic rewards are the tangible rewards. These rewards may include pay, benefits, and promotions [15].

The provision of organizational rewards indicates that the organization values and recognizes the contributions of employees for the organization [16]. The organizational rewards show that organization is keen to invest in employees. Moreover, the rewards are an indication of organizations' interest in its employees in the form of their recognition and appreciation $[4,17]$. The rewards whether, intrinsic or extrinsic are likely to develop a feeling among the employees that the organization values them and makes them more committed to their organization. According to Fasolo [13], support from organization enhances thinking of employees that organization regards that they are performing their jobs very well. The rewards also develops feeling that organization honors the achievements of employees. The rewards also result in helping employees to develop esteem. However, the fairness in the provision of rewards is necessary in developing such feelings and making employees committed to their organization.

In a recent study, Landsman [18] has found that if employees believe that their organization is fair in the distribution of rewards, and punishments, they become more committed to their employer. The organizational commitment of employees increases in this way as a result of their satisfaction with the job. Hence, we propose the following hypothesis:

H1: The higher the organizational rewards (monetary and non-monetary) the higher the employee commitment to their organization.

Many at times, employees feel that the support they receive from their immediate supervisors may be attributed to the support of the organization for them [19]. Perceived supervisor support strengthens a feeling of obligation among employees to work in return for the betterment of their organization and to help the organization to achieve its objectives. Such feelings increase the affective commitment, and resultantly the turnover and withdrawal of employees from their organization decreases $[4,20]$.

According to Malatesta [21], the norm of reciprocity also explains the increased obligations to supervisor and organization from the employees based on support received from supervisor. If support from the supervisor is low, employees can possibly believe that they may handle the unfavorable situations by adapting to new supervisor or by decreasing the frequency of contact to their supervisor while keeping up with routine job tasks. It was further concluded that lower supervisor may have serious implications for the career in the belief of the employees. Therefore, better relationships between subordinate and supervisor result in employees' feeling of higher support from the organization [19].

Employees feel that the supervisor is an agent of the organization with the mandate giving the directions and evaluating the performance of subordinates. In this regard, employees feel that the treatment they receive from them is an indication of the orientation of their organization towards them [17]. The level to which employees feel that they receive support from their supervisor affects the satisfaction of employees. It also leads to the emotional attachment to their organization and their job satisfaction. Hence, the contribution of supervisor towards the development of organizational commitment among employees cannot be ignored [18]. Therefore, we can propose the following hypothesis:

H2: Higher the support received from supervisor, higher the employee organizational commitment.

Career development means the upward advancement on the ladders of hierarchy in a job. One of the fundamental motivations for joining and committing with an organization the level of opportunities that the organization provides for the growth of career. According to Tansky and Cohen [22] the availability of opportunities to grow in the career are important for developing organizational commitment among employees. They further suggest that an organization should have a formal mechanism for the purpose of developing the careers of employees. This kind of a program may be planned to help the worker to advance in their career endeavors not only within the organization but outside. These activities help for the retention of employee over an extended time period. They also facilitate in achieving the long term plans. Career development opportunities mainly include promotions on the job while moving up the ladder, and the training of the necessary skills needed to perform the job. Possibility of promotions on the job may have multipronged benefits for the organization. Employees feel more satisfied with their job, they exert extra effort to perform the job and intend to keep their long term relationships with the organization. Moreover, the word of mouth of employees may help to attract to the best talent for the organization. The training activities are the other facet of career growth opportunities. The training activities develop the skills of employees and makes them better able to perform the job, hence leading to greater organizational performance. Researchers have empirically held that training opportunities enhance the acumen of employees and improves satisfaction and commitment among them [2325].

Furthermore, we can explain the relation between career development and organizational commitment in the perspective of psychological contract theory. The availability of career plans binds employees into a psychological contract with their organization and foster their commitment [23]. This feeling aligns the individual goals with the organizational goals, and makes them committed to their organization [26]. Nadler and 
Nadler [27] argue that the career development activities that the organization initiates for the development of employees makes employees feel that they are being valued. In this way, the norm of reciprocity comes into play. The employees then reciprocate the efforts of the organization for them. Employees take the career development opportunities as the encouraging activities for them from their organization. Hence, based on this discuss we deduce the hypothesis as follows:

H3: more the provision of opportunities for the development of career, more will be the employee commitment to the organization.

Family matters have important place in the life spheres of employees. A higher level of contentment and satisfaction in the family life leads to higher performance in the workplace. If the organization provides a higher level of support to the employees in their family responsibilities, it is very likely that they will take their organization as very caring and considerate of their needs [28]. The support from the organization will be reciprocated by the employees for their organization. The benefits that employees receive for their family will enhance their commitment to their organization [29]. It has been proposed that benefits which the employees receive from their organization to enhance the perception among employees of higher levels of organizational support from employer and in turn relates to turnover intentions negatively and organizational commitment positively [20].

According to the evidence from a study [30], the work-life benefits availability is related to lower turnover intentions and higher commitment among employees. The provision of work-life benefits signals to the employees that the organization cares for them and enhances their attachment to the organization. According to Allen [28] the organizations providing more work-life assistances are perceived as more supportive to family. Moreover, he found that arrangements such as flexible timing, compact work schedules, and family leave policies were highly related to the higher organizational commitment and less turnover intentions. Therefore, we propose the following hypothesis.

H4: The higher the organizational support for family, the higher will be the employee commitment.

Another important factor leading to better performance, satisfaction, and commitment is the favorable job conditions. These conditions include the attributes of the job. A job is highly favorable if it has security, autonomy and empowerment.

Job security is the possibility that an employee remains in the employment of an organization for a longer period with no such negative consequences as diminished seniority, pay, or pension rights [31]. According to Herzberg [32], job security may be defined as the extent of stability of employment for employees within an organization. The provision of job security has its importance for resulting in many favorable outcomes for the organization. The consequences of job security may be lower employee turnover [33], increased job satisfaction [34], higher physical and psychological well-being of employees [35] and higher organizational commitment [36]. The higher organizational commitment among employees happens as an exchange phenomena between employee employer relations. The employees therefor become more committed to their employer and avoid turning over [37].

Work discretion/autonomy is an aspect of job conditions deemed favorable by the employees. Work discretion is the freedom to act independently. Discretionary work environments give employees the access to resources, information, provide learning and growth opportunities Those having such roles in their jobs perform better than others and are more committee [38]. These actions of the employer make employees feel that their organization trusts upon them. In exchange, the possible result is the higher employee commitment. Therefore, we propose the following hypothesis:

H5: Highly favorable job conditions are related to higher commitment of employee to the organization. The following schematic model summarizes all the above discussion.

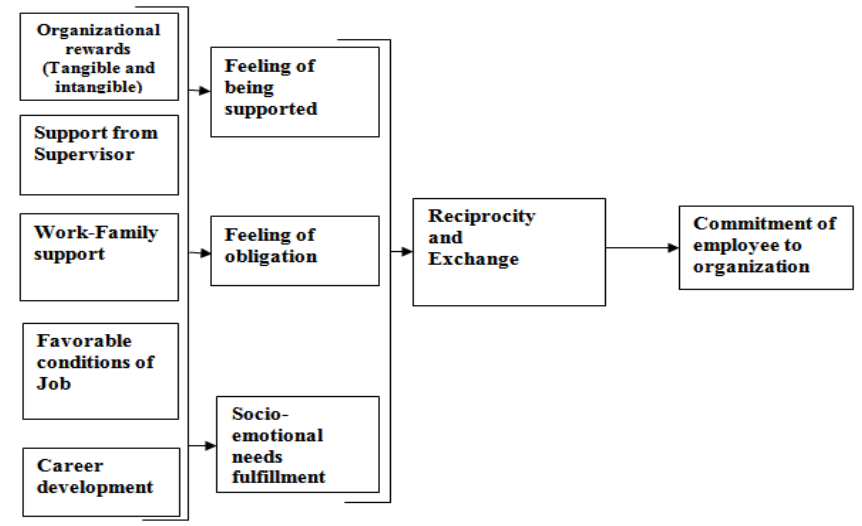

(Fig 1: Conceptual Model) 


\section{Methodology}

Data Collection: The objective of the study was to explore the factors which may enhance the commitment among officers working in the banks in Pakistan. In lieu of time and cost limitations, we used the survey research methodology. Surveys are beneficial since they enhance the response rates by ensuring the respondents' anonymity. The population of the present study was all the employees working in officer cadres. The other criterion was, only those officers constituted the population who had been inducted through a special induction program. The program is, "Management Trainee Officers Program". After an intensive training of one year, the officers are posted to their relevant jobs in the relevant departments. The third criterion was those who had passed their probation periods. The sample consisted of 147 officers of different banks selected from the city of Lahore, Pakistan.

Measures: The dependent variable Organizational commitment was measured by a widely used questionnaire which has been developed by Mowday, Steers [39]. There were total 14 statements measuring organizational commitment along the dimension of (a) willingness to exert extra effort for the organization (2 items); (b) attachment with organization (8 items); and (c) support for the organization and goals of the organization ( 4 items). The reliability of the scale was $\alpha=0.79$.

The independent variables organizational rewards, supervisor support, career development opportunities, family support, and favorable job conditions were measured using items adapted from the perceiving organizational support scale of Eisenberger, Huntington [3]. Organizational rewards were measured using 8 items both for tangible and intangible rewards with $\alpha=.714$. Supervisor support was measured along the dimensions of guidance, equal treatment, and cooperation with the subordinates using 7 items with $\alpha=.800$. For measuring career development opportunities, 10 items were included in the questionnaire along the dimensions of training opportunities, development opportunities, and promotion opportunities. The reliability of this scale was $\alpha=.85$. Support for family was measured using 2 items with $\alpha=.81$. The favorable job conditions were measured using 6 items along the dimensions of security and discretion with $\alpha=.72$. The multiple regression model was applied. Before running the regression the data were screened and checked for regression assumptions. The analysis was performed using SPSS version 21 .

\section{Analysis And Discussion}

The table below (see table 1) is a table of correlations between organizational commitment and the factors affecting organizational commitment. The table shows that the correlations among the variables of our study are are significant. The variable organizational rewards (intangible and tangible) have a positive correlation with the commitment at a strength of 0.394 and a level of significance of 0.05 . The construct of supervisor support and organizational commitment have a positive correlation with a correlation coefficient of 0.385 at $\mathrm{p} \leq 0.05$. This conforms to the Landsman [18] conclusion, wherein he found the correlation strength of 0.26 between organizational commitment and supervisor support.

Table 1: Correlations among variables in study

\begin{tabular}{|c|c|c|c|c|c|c|}
\hline & 1 & 2 & 3 & 4 & 5 & 6 \\
\hline 1. Organizational Commitment & 1 & & & & & \\
\hline 2. Organizational Rewards & $.394^{*}$ & 1 & & & & \\
\hline 4. Work-family Support & $.479^{* *}$ & $.601^{* *}$ & $.352^{*}$ & 1 & & \\
\hline 5. Career Opportunities & $.648^{* *}$ & $.553^{* *}$ & $.487^{* *}$ & $.471^{* *}$ & 1 & \\
\hline
\end{tabular}

*. Correlation is significant at the 0.05 level (1-tailed).

**. Correlation is significant at the 0.01 level (1-tailed).

The variable of family support shows a significant positive correlation coefficient of 0.479 with the organizational commitment at $\mathrm{p} \leq 0.01$. This correlation coefficient is well above the study of Dockel, Basson [40]. They found a correlation coefficient of 0.31. This is also in conformance with the study of Balmforth and Gardner [41]. Career opportunities are the next variable for which the table of correlations shows the correlation coefficient.

The third factor career opportunities show a strong correlation coefficient of 0.648 at $p \leq 0.01$. Our result of career opportunities strong correlation with organizational commitment has also its support in previous studies [40]. However, our study shows a bit higher correlation as compared to the previous study. [26] argued that the feeling among employees to keep committed and grow with the organization is significantly influenced by the provision of career opportunities. Favorable job conditions is last and fifth factor in our study is believed to significantly affect organizational commitment among bank officers. 
Job conditions and organizational commitment show a correlation coefficient of 0.659 between them at a significance level of $\mathrm{p} \leq 0.01$. Previously, researchers [40] have found no significant correlation between organizational commitment and job characteristics. In contrast, Steers [42] have found that there is a positive significant correlation between organizational commitment and favorable job conditions.

The regression coefficients are shown in table 2. The independent variables job conditions, family support, career opportunities, supervisor support, and organizational rewards together explain a variation of 38 $\%$ in the dependent variable. All the regression coefficients shown in the table (see table 2) show that they are positively related to the dependent variable of organizational commitment. However, the beta coefficient for organizational rewards is at the least level as compared to other variables. An increase of one percent in organizational rewards increases the commitment up to 2 percent. However, we conclude that if higher rewards are given by the organization, higher will be the commitment among employees towards their organization. This result is consistent with our theoretical framework $[13,18]$.

Table 2: Regression Coefficients

\begin{tabular}{|c|c|c|c|c|c|}
\hline \multirow{2}{*}{\multicolumn{2}{|c|}{ Model }} & \multicolumn{2}{|c|}{ Unstandardized Coefficients } & \multirow{2}{*}{$\begin{array}{c}\begin{array}{c}\text { Standardized } \\
\text { Coefficients }\end{array} \\
\text { Beta }\end{array}$} & \multirow[b]{2}{*}{$\mathrm{T}$} \\
\hline & & $\mathrm{B}$ & Std. Error & & \\
\hline \multirow[t]{6}{*}{1} & (Constant) & 10.964 & 8.977 & & 1.221 \\
\hline & Organizational Rewards & .022 & .337 & .013 & .066 \\
\hline & Supervisor support & .166 & .333 & .087 & .499 \\
\hline & Work-Family Support & .388 & .549 & .127 & .708 \\
\hline & Career Opportunities & .608 & .404 & .310 & 1.505 \\
\hline & Job Conditions & .833 & .369 & .445 & 2.259 \\
\hline \multirow{2}{*}{\multicolumn{2}{|c|}{ a. Dependent Variable: OC }} & & \multicolumn{2}{|c|}{$\begin{array}{l}\text { Adjusted R } \\
\text { Square }=0.384\end{array}$} & $\mathrm{~F}=4.679$ \\
\hline & & \multicolumn{4}{|c|}{ Significance $=.004$} \\
\hline
\end{tabular}

The second regression coefficient in the table is related to support from supervisor. Supervisor support has a considerable effect on officers' commitment towards their bank. If the support from the supervisor is increased by 1 percent, the officer will show an increase of 16 percent commitment towards his bank. Our results are consistent with the earlier researchers [3]. We have statistical support to accept our hypothesis. A higher level of support from the supervisor is likely to increase commitment among employees.

Work-family support reports a beta coefficient of 0.388 as shown in the table below (see table 2). Commitment towards the employing bank by the officer results positively from the work-family support of organization for the employee. The hypothesis that higher the support for family issues, higher the commitment may empirically be presented as a 1 percent increase in work-family support is likely to increase 38 percent commitment among officers. Allen [28], Casper and Harris [29], and Grover and Crooker [30] have also found the similar results in their studies.

The regression analysis show (see table 2) we have support to accept our hypothesis that provision of career opportunities positively affects the commitment among bank officers. In fact career opportunities are likely to increase as high as 60 percentage change in the commitment of officers. Previous studies [22-25] have also concluded the similar results. Thus, our results are validated in this regard.

The final variable of our study, which has been hypothesized to affect the organizational commitment among officers of the bank is favorable job conditions. The statistical evidence shows that by making job conditions favorable up to one percent, the commitment among officers increases by 83 percent. Hence we can claim to accept our hypothesis and have support of studies in the similar line [35].

The above discussion presents us detailed analysis of how various factors are correlated with organizational commitment and can affect the same. The results of analysis supplement the earlier studies [4345]. It has been observed that various independent variables have a positive effect on the dependent variable of employee commitment. Makanjee, Hartzer [45] have studied the radiographers for their commitment towards their organization. They found that commitment is driven by factors like rewards, work-family support, supervisor support, job characteristics, and career opportunities. However, we found that literature lacks in terms of studies on bank officers.

The theoretical underpinnings of our study hold that as a result of provision of different kinds of support from the organization to the employee, it is likely that the commitment of employee to their employer will increase as explained by the norm of reciprocity theory. Furthermore, the theory of social exchange refers that those who are treated fairly by others will repay as a phenomenon of exchange between the two parties entering into an exchange relationship [46]. Thus the norm of reciprocity comes as a result of the exchange. Organizational settings are also characterized by such exchanges. While these exchanges occur in the 
organizational environment, the employees identify their goals with the goals of the organization, they exert extra effort, and keep attached to the employer who supports them [43]. The whole discussion above shows that the officers of the bank become more committed as a result of support while endorsing the theory of social exchange and the norm of reciprocity.

\section{Conclusion And Recommendations}

The study investigates the factors which enhance the commitment of bank officers. In the context, this kind of a stud is unique in itself. The factors of rewards, support from supervisor, work-family support, job conditions, and career growth opportunities were hypothesized to have a positive effect on commitment of officers towards their organization based on the phenomenon of exchange and reciprocity as the main theoretical underpinnings of this research. The results suggest that if the organization wants to have a higher commitment of its officers, the outlined factors in the study may be improved. Thus, employees in turn will exhibit such behaviors as beneficial to the organization.

Lew and Felt [44] found that employee commitment brings a lot of benefits to the organization. These may include higher levels of satisfaction, extra work, and improved performance. Thus the provision of said support will result into a commitment which in turn will lead to satisfaction, and heightened performance. The employees will repay their organization for sure. The organization must ensure easy and lucrative career progression as a basic right to the employees. Highly qualifies employees have a higher appetite for growth. Thus the key to retention of the best talent is the provision of career paths. Support should also extend beyond the workplace and may involve the family as well. Employees since having invested in monetary terms in their academic careers want a return on that investment. The employer should recognize this fact.

\section{References}

[1] Blau, P., M. . Exchange and power in social life. New York Wiley, 1964.

[2] Gouldner, A.W., The norm of reciprocity: A preliminary statement. American Sociological review, 1960. 25: p. 161-178.

[3] Eisenberger, R., et al., Percieved Organizational Support. Journal of Applied Psychology, 1986. 71: p. $500-507$.

[4] Shore, L.M. and T.H. Shore, Perceived organizational support and organizational justice. Organizational politics, justice, and support: Managing the social climate of the workplace, 1995: p. 149-164.

[5] Bateman, T.S. and S. Strasser, A longitudinal analysis of the antecedents of organizational commitment. Academy of management journal, 1984. 27(1): p. 95-112.

[6] Meyer, J.P. and L. Herscovitch, Commitment in the workplace: Toward a general model. Human resource management review, 2001. 11(3): p. 299-326.

[7] Allen and Meyer, Affective, Continuance, and Normative Commitment to the Organization: An Examination of Construct Validity. Journal of vocational behavior, 1996. 49(3): p. 252-76.

[8] Mowday, R.T., Reflections on the study and relevance of organizational commitment. Human resource management review, 1999. 8(4): p. $387-401$

[9] Morrow, P.C., The theory and measurement of work commitment. 1993, Greenwich: JAI Press.

[10] Guzzo, R.A., K.A. Noonan, and E. Elron, Expatriate managers and the psychological contract. Journal of Applied psychology, 1994. 79(4): p. 617.

[11] Wayne, S.J., L.M. Shore, and R.C. Liden, Perceived organizational support and leader member exchange:A social exchange perspective. Academy of Management Journal, 1997. 40: p. 82-111.

[12] Hutchison, S. and M.L. Garstka, Sources of Perceived Organizational Support: Goal Setting and Feedback1. Journal of Applied Social Psychology, 1996. 26(15): p. 1351-1366.

[13] Fasolo, P., Procedural justice and perceived organizational support: Hypothesized effects on job performance. Organizational politics, justice, and support: Managing social climate at work, 1995: p. 185-195.

[14] Malhotra, N., P. Budhwar, and P. Prowse, Linking rewards to commitment: an empirical investigation of four UK call centres. The International Journal of Human Resource Management, 2007. 18(12): p. 2095-2128.

[15] Williamson, I.O., M.F. Burnett, and K.M. Bartol, The interactive effect of collectivism and organizational rewards on affective organizational commitment. Cross Cultural Management: An International Journal, 2009. 16(1): p. 28-43.

[16] Eisenberger, R., P. Fasolo, and V. Davis-LaMastro, Perceived organizational support and employee diligence, commitment, and innovation. Journal of Applied Psychology, 1990. 75(1): p. 51-59.

[17] Eisenberger, R., et al., Perceived organizational support, discretionary treatment, and job satisfaction. The Journal of applied psychology, 1997. 82(5): p. 812-20.

[18] Landsman, M.J., Pathways to Organizational Commitment. Administration in Social Work 2008. 32(2).

[19] Eisenberger, R., et al., Perceived supervisor support: contributions to perceived organizational support and employee retention. Journal of applied psychology, 2002. 87(3): p. 565.

[20] Rhoades, L. and R. Eisenberger, Perceived organizational support: a review of the literature. The Journal of applied psychology, 2002. 87(4): p. 698-714.

[21] Malatesta, R.M., Understanding the dynamics of organizational and supervisory commitment using a social exchange framework. 1995: UMI Dissertation Services.

[22] Tansky, J.W. and D.J. Cohen, The relationship between organizational support, employee development, and organizational commitment: An empirical study. Human Resource Development Quarterly, 2001. 12(3): p. 285-300.

[23] Harel, G.H. and S.S. Tzafrir, The effect of human resource management practices on the perceptions of organizational and market performance of the firm. Human Resource Management, 1999. 38: p. 185-200.

[24] Kalleberg, A.L. and J.W. Moody, Human resource management and organizational performance. American Behavioral Scientist, 1994. 37: p. 948-962. 
[25] McEvoy, M.G., Organizational change and outdoor management education. Human Resource Management, 1997. 36: p. $235-250$.

[26] Okpara, J.O., Job satisfaction and organizational commitment: Are there differences between American and Nigerian managers employed in the US MNCs in Nigeria. Academy of Business \& Administrative Sciences, Briarcliffe College, Switzerland, 2004.

[27] Nadler, L. and Z. Nadler, Developing human resources. 1989: Jossey-Bass Publishers.

[28] Allen, T.D., Family-supportive work environments: The role of organizational perceptions. Journal of vocational behavior, 2001. 58(3): p. 414-435.

[29] Casper, W.J. and C.M. Harris, Work-life benefits and organizational attachment:Self-interest utility and signaling theory models. Journal of Vocational Behavior, 2008. 72(2008 SRC - GoogleScholar): p. 95-109.

[30] Grover, S.L. and K.J. Crooker, Who appreciates family-responsive human resource policies: The impact of family-friendly policies on the organizational attachment of parents and non-parents. Personnel psychology, 1995. 48(2): p. 271-288.

[31] Meltz, N.M., Job security in Canada. Relations industrielles/Industrial Relations, 1989: p. 149-161.

[32] Herzberg, F.I., Work and the nature of man. 1966.

[33] Arnold, H.J. and D.C. Feldman, A multivariate analysis of the determinants of job turnover. Journal of Applied Psychology, 1982. 67(3): p. 350.

[34] Lim, V.K., Job insecurity and its outcomes: Moderating effects of work-based and nonwork-based social support. Human relations, 1996. 49(2): p. 171-194.

[35] Burke, R.J., Job insecurity in stockbrokers: effects on satisfaction and health. Journal of Managerial Psychology, 1991. 6(5): p. 1016.

[36] Morris, T., H. Lydka, and M.F. O'Creevy, Can commitment be managed? A longitudinal analysis of employee commitment and human resource policies. Human Resource Management Journal, 1993. 3(3): p. 21-42.

[37] Rousseau, D., Psychological contracts in organizations: Understanding written and unwritten agreements. 1995: Sage.

[38] Cho, J., H.K.S. Laschinger, and C. Wong, Workplace empowerment, work engagement and organizational commitment of new graduate nurses. NURSING LEADERSHIP-ACADEMY OF CANADIAN EXECUTIVE NURSES-, 2006. 19(3): p. 43.

[39] Mowday, R.T., R.M. Steers, and L.W. Porter, The measurement of organizational commitment. Journal of vocational behavior, 1979. 14(2): p. 224-247.

[40] Dockel, A., J.S. Basson, and M. Coetzee, The effect of retention factors on organisational commitment: An investigation of high technology employees. SA Journal of Human Resource Management, 2006. 4(2): p. p. 20-28.

[41] Balmforth, K. and D. Gardner, Conflict and Facilitation between Work and Family: Realizing the Outcomes for Organizations. New Zealand Journal of Psychology, 2006.

[42] Steers, R.M., Antecedents and outcomes of organizational commitment. Administrative science quarterly, $1977:$ p. 46-56.

[43] Somech, A. and R. Bogler, Antecedents and consequences of Teacher organizational and professional commitment. Educational Administration Quarterly, 2002. 4: p. 555-577.

[44] Lew, T.Y. and S. Felt, The Relationships between Perceived Organizational Affective Organizational Commitment and Turnover Intention of Academics working with Private Higher Educational Institutions in Malaysia. European Journal of Social Sciences, 2009. 9(1): p. 72-87.

[45] Makanjee, C.R., Y.F. Hartzer, and I.L. Uys, The effect of perceived organizational support on organizational commitment of diagnostic imaging radiographers. Radiography, 2006: p. 118-206

[46] Gouldner, A.W., The norm of reciprocity: A preliminary statement. American sociological review, 1960: p. 161-178. 